\title{
A systematic review on the modifications of extracellular vesicles: a revolutionized tool of nano-biotechnology
}

\author{
Alok Raghav ${ }^{1}$ and Goo-Bo Jeong ${ }^{2^{*}}$ (D)
}

\begin{abstract}
Background: Tailoring extracellular vesicles (EVs) can bequeath them with diverse functions and efficient performance in nano-biotechnology. Engineering and modification of EVs improves the targeted drug delivery efficiency. Here, we performed systematic review of various methods for EVs modifications.

Methods: PubMed, Scopus, ISI Web of Science, EMBASE, and Google Scholar were searched for available articles on EVs modifications (up to March 2021). In total, 1208 articles were identified and assessed, and then only 36 articles were found eligible and included.

Results: Six studies demonstrate the application of click chemistry, seven studies used co-incubation, two studies used chemical transfection, four studies implicated electroporation and sonication approach for modification of EVs. Moreover, two studies utilized microfluidics as suitable approach for loading cargo into EVs, while eight studies showed freeze-thaw method as feasible for these biological nanoparticles.

Conclusion: Freeze-thaw approach is found to be convenient and popular among researchers for performing modifications in EVs for the purpose of targeted drug delivery loading. Clinical-grade EVs production with good clinical practices (GCPs) is challenging in the current scenario. More studies are needed to determine the best suitable approach for cargo loading of EVs that may be exploited for research and therapeutic use.
\end{abstract}

\section{Highlights}

- Extracellular vesicles (EVs) can be modified using various methods available including physical, chemical and engineering based. These tailoring methods are helpful in targeting drug delivery to treat various diseases. Moreover, EVs have the ability to modify that's due to presence of lipid bilayer membrane, that's effectively participate in loading and unloading of desired drug.

- EVs expressed from the specific cell types can give useful information about the pathogenesis of a particular disease in the form of unique nucleic acids, protein and lipid sequences and therefore, EVs derived from these cells can be used as specific diagnostic biomarker for diagnosis of diseases.

- Modified EVs using various drugs or miRNAs can be used for targeted drug delivery to specific cells.

*Correspondence: gbjeong@gachon.ac.kr

2 Department of Anatomy and Cell Biology, College of Medicine, Gachon

University, 155 Getbeol-roYeonsu-gu, Incheon 21999, Korea

Full list of author information is available at the end of the article

(c) The Author(s) 2021. Open Access This article is licensed under a Creative Commons Attribution 4.0 International License, which permits use, sharing, adaptation, distribution and reproduction in any medium or format, as long as you give appropriate credit to the original author(s) and the source, provide a link to the Creative Commons licence, and indicate if changes were made. The images or other third party material in this article are included in the article's Creative Commons licence, unless indicated otherwise in a credit line to the material. If material is not included in the article's Creative Commons licence and your intended use is not permitted by statutory regulation or exceeds the permitted use, you will need to obtain permission directly from the copyright holder. To view a copy of this licence, visit http://creativecommons.org/licenses/by/4.0/. The Creative Commons Public Domain Dedication waiver (http://creativeco mmons.org/publicdomain/zero/1.0/) applies to the data made available in this article, unless otherwise stated in a credit line to the data. 


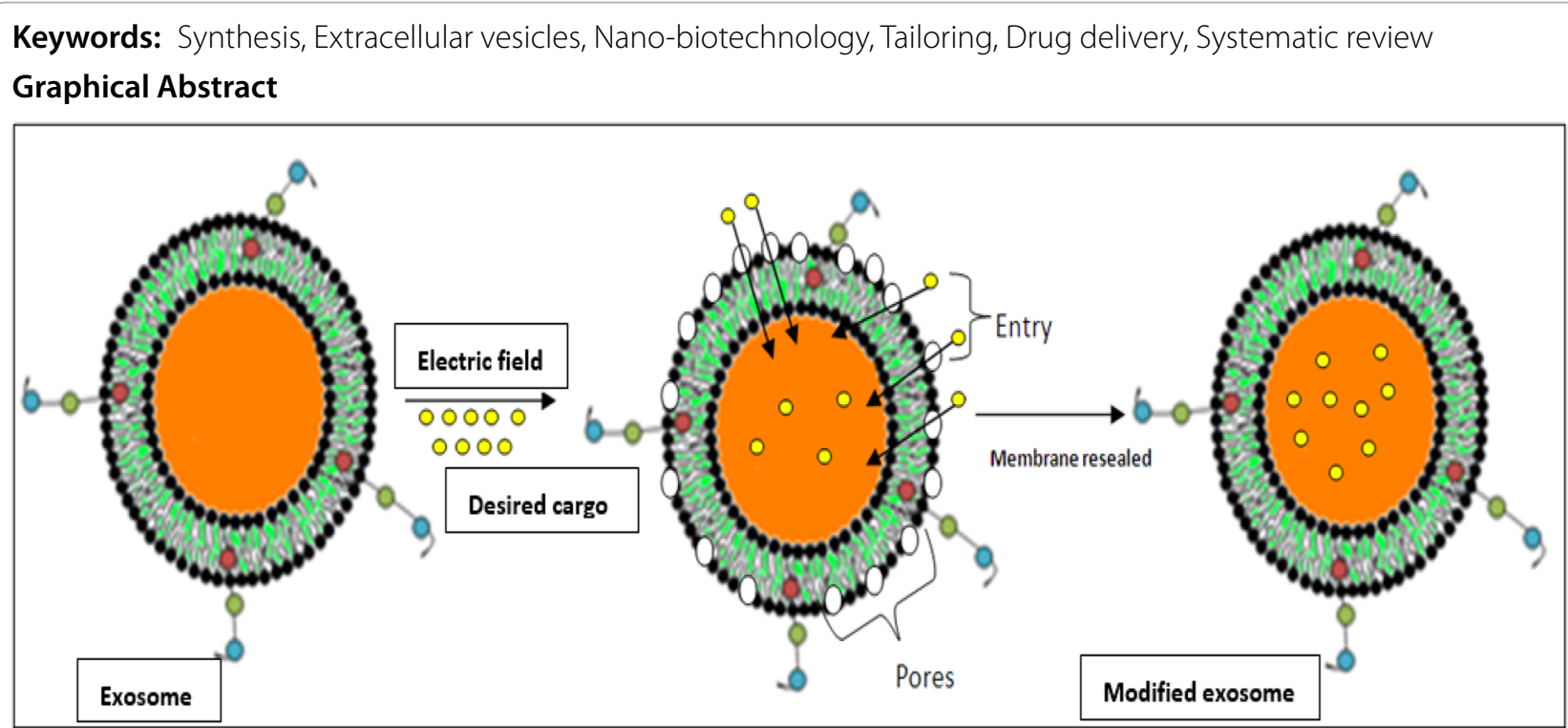

\section{Introduction}

Extracellular vesicles (EVs) are naturally occurring nanoparticles of endosomal origin released from a wide variety of cells. They are membrane-bound vesicles ranging in size from $30-150 \mathrm{~nm}$ with a cup-shaped morphology, as seen under a scanning electron microscope (SEM), along with a floatation density of $1.10-1.21 \mathrm{~g} / \mathrm{mL}$ in a sucrose gradient column [1]. The exosomal cargo is mostly rich in proteins (including tetraspanins $(\mathrm{CD} 9, \mathrm{CD} 63$, and $\mathrm{CD}$ 81), MHC class I and II, and heat shock proteins (HSP 60, 70, and 90), lipids, sugars, and nucleic acids [2]. The cargo imparts functionality to the EVs for different cellular communications, like paracrine, autocrine, endocrine and/or juxtacrine signaling [3], while surface proteins identify the EVs for cargo delivery.

Three types of EVs exist that are classified based on size and biogenesis, the smallest being exosomes $(30-150 \mathrm{~nm})$, followed by microvesicles and apoptotic bodies (larger than $100 \mathrm{~nm}$ ). EVs are released into the extracellular environment after multivesicular bodies (MVBs) fuse with the plasma membrane, while microvesicles and apoptotic bodies are released directly by the plasma membrane of living and dying cells, respectively. EVs release involves various steps: the formation of early endosomes, the fusion of MVBs containing intraluminal vesicles (ILVs) with the plasma membrane by exocytosis, and the release of EVs in the extracellular space [4]. EVs are present in all bodily fluids secreted by cells, including blood [5], urine [6], plasma [7], breast milk [8], saliva [9], bile, synovial fluid, semen, amniotic fluid, ascites fluid (peritoneal cavity), and bronchoalveolar and gastrointestinal lavage fluid [10]. Biomolecules present both inside and on the surface of EVs are important markers for their isolation and characterization. As per the International Society for Extracellular Vesicles (ISEV), vesicles isolated from any type of extracellular fluids (i.e., any bodily fluids or cell culture-conditioned media) are referred to as EVs [11]. ISEV has also defined experimental guidelines for the characterization of EVs [11].

Liposomes, micelles, and polymer-based nanomaterials are the most commonly used drug delivery agents for clinical studies, and these have been curated over time to improve the solubility, efficacy, and stability of drugs [12]. However, clinical trials with these systems have been associated with limitations like immunogenicity, poor bio-distribution, and a short half-life. Therefore, to overcome these limitations, researchers have sought alternatives for delivery vehicles that are endogenous to the cells/tissue.

EVs have been exploited as drug delivery vehicles in several studies and possess an edge over the available drug delivery protocols in therapeutics [12-14]. Figure 1 depicts the increasing global trend in publications related to EVs research over the past 30 years (1989-2019). The dynamic composition of EVs allows for the tailoring of a "cargo of interest" for enhanced efficacy and specificity. Additionally, EVs may be modified for prolonged circulation time, specific target cell recognition using cell surface markers, negligible toxicity, and immune tolerance. 

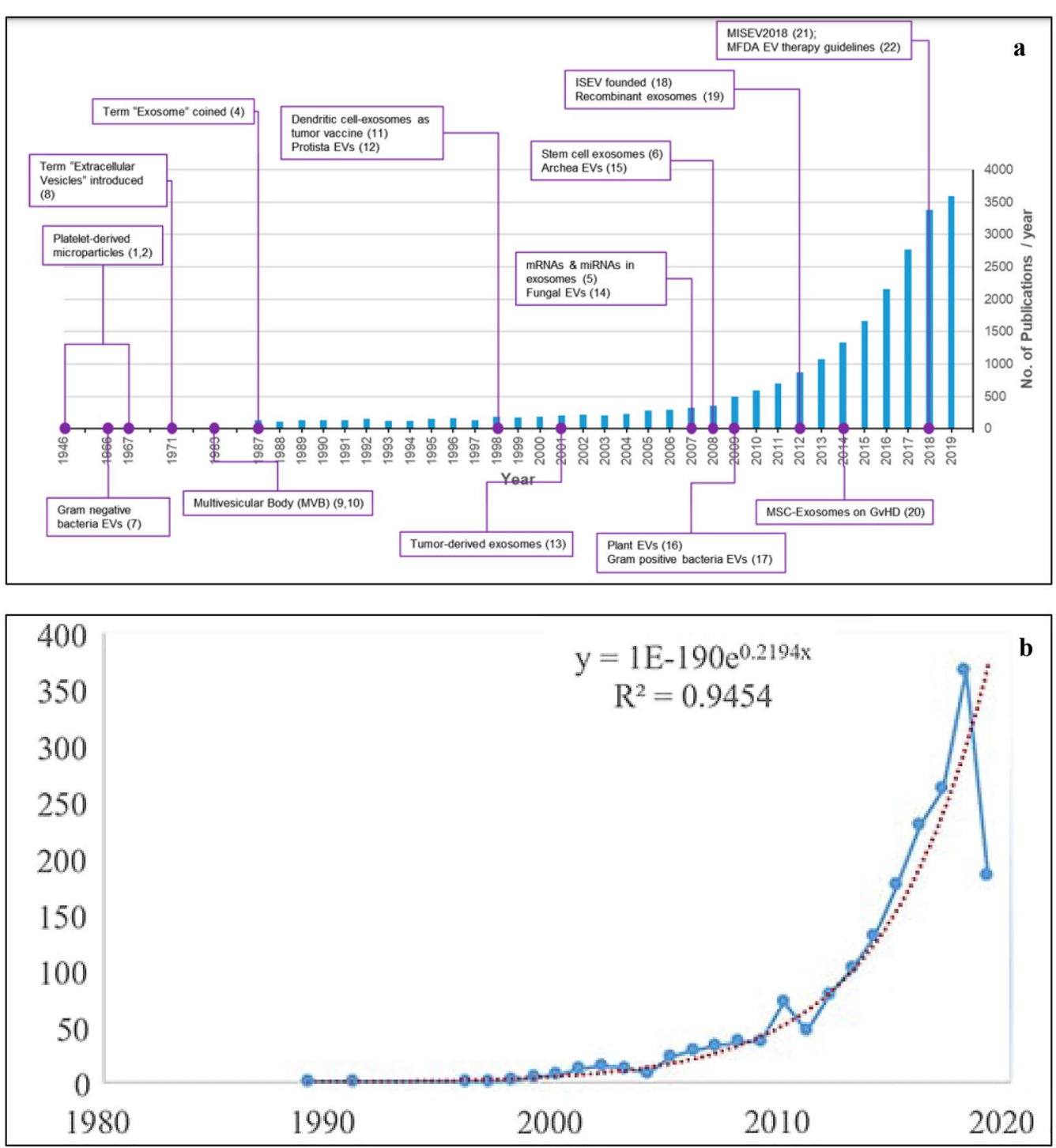

Fig. 1 a Trends of publications and major discoveries regarding exosomes. b Publication trends in Exosome research field from 1989 to 2019 (red dotted line: the prediction trends, blue line: the original trends). (Adapted from Reference [62] and [63] respectively under open access article distributed under the Creative Commons Attribution License)

EVs can be simultaneously manipulated with multiple types of deliverables, like drugs, proteins, and coding/ non-coding nucleic acids. However, further studies are required to evaluate whether there exists any sort of allogeneic immune rejection among EVs from different donors and recipients $[15,16]$.

EVs have a diverse physiological role in the immune system, cell-to-cell interaction, central nervous system (CNS), tissue regeneration therapeutics, cardiovascular diseases (CVDs) and COVID-19 [17]. Moreover, the definite role of EVs remains elusive. In previously published literature it was found that EVs extracted from the dendritic cells (DCs) bearing peptide MHC-I, II, CD80/B7.1 and CD86/B7.2 induces immunomodulation through activation of CD4+ and CD8+ T-lymphocytes [17]. EVs were also found to mediate immunosuppressive effects on natural killer (NK) cells and T lymphocytes [17]. EVs derived from oligodendrocytes (ODCs) enriched with prime components of the myelin sheaths including myelin basic protein (MBP), myelin proteolipid protein (PLP) and oligodendrocyte glycoprotein (OG) along with 


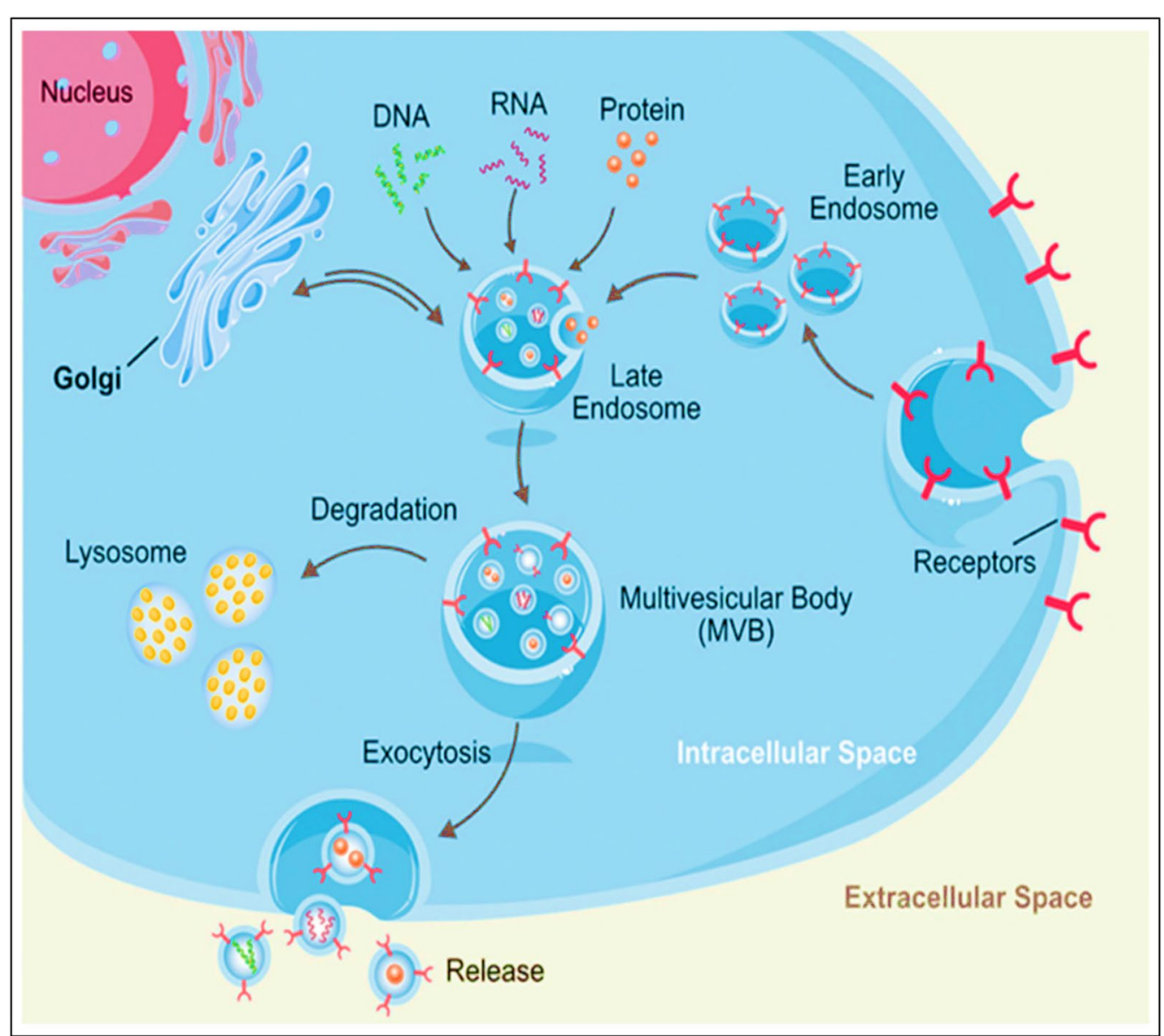

Fig. 2 Pictorial representation of EVs biogenesis. MVB, multivesicular bodies. (Adapted from Ref No. [67] under Creative Commons Attribution License 4.0)

several essential factors and protein that is needed for the vital functioning of axons [18]. In one of the previously published studies, ODCs derived EVs helps in protecting neurons from oxidative stress (OS) and control the biogenesis of the myelin sheaths (MS) [19]. EVs also play important role in angiogenesis and cardiovascular diseases (CVDs). In one of the previously published study, it was found that EVs derived from the CD34+stromal cells showed a therapeutic effect on angiogenesis, both in-vitro and in-vivo [20]. In another human study, EVs showed a cardio-protecting role in myocardial ischemia (MI) reperfusion injury mediated through paracrine effects of these EVs [21]. This review predominantly focuses on recent approaches used for EVs modification and clinical applications of these EVs for therapy and diagnostics.

EVs biogenesis is a constitutive phenomenon that is initiated with an inward invagination of the plasma membrane, leading to the formation of early and late endosomes in the cytosol by the cells. The late endosome/MVB membrane invaginates further and forms ILVs inside large MVBs. Inward invagination of the endosomal membrane is accompanied by the engulfment of several proteins and numerous cytosolic components. Later, these MVBs fuse with the plasma membrane and release the EVs by exocytosis in the extracellular space, as depicted in Fig. 2. Previous studies have elucidated that MVB biogenesis [17], vesicle budding, and EVs cargo sorting are either dependent on or independent of the endosomal sorting complex required for transport (ESCRT), which is complex protein machinery consisting of four subunits, (0 to III). The ESCRT-mediated cargo sorting mechanism involves the identification and sequestration of ubiquitinated proteins to specific sites of the endosomal membranes. Further, sequential interaction with other 
subunits (I, II, and III) completes the complex and initiates the budding process. Sorting protein Vps4 helps in the detachment of the ESCRT III complex from the MVB membrane, leading to the formation of ILVs from cleaved buds. Meanwhile, the ESCRT-independent mechanism involves the interplay of proteins and lipids, such as tetraspanins (CD81), ceramides and others. Whether or not EVs biogenesis and cargo sorting will be ESCRT-dependent/independent primarily depends on the parent cell type responsible for EVs production, and this, in turn, is affected by the physiological status of the parent cells stimulated, stressed, or differentiated).

Diverse cell lineages secrete EVs with various cargo contents (proteins, lipids, and nucleic acids) [18]. A major proportion of the cargo comprises proteins, such as tetraspanins, heat shock proteins, cell adhesion proteins, membrane transport proteins, cell-signalling proteins, transcription proteins, and trafficking membrane fusion proteins. Moreover, lipid-profiling studies have revealed that phosphatidylserine (PS), phosphatidicacid, cholesterol, sphingomyelin (SM), arachidonic acid, prostaglandins, leukotrienes, and other fatty acids are some of the lipids commonly found in EVs. In addition to lipid components, EVs contain diverse non-coding RNAs, including miRNA, small nuclear RNA, small nucleolar RNA, long non-coding RNA, piwi-interacting RNA, rRNA, and tRNA [19-25].

In this systematic review, we present the currently available knowledge concerning suitable methods for the loading or delivering of the desired cargo into EVs that can be further translated for clinical purposes, such as in the treatment of various diseases. Our analysis provides evidence-based help for researchers and clinicians to exploit the field of EVs.

\section{Materials and methods}

The present systematic review was framed following the Preferred Reporting Items for Systematic Reviews and Meta-Analyses (PRISMA) guidelines [26].

\section{Literature search}

Published articles were selected from PubMed, Scopus, ISI Web of Science, EMBASE, and Google Scholar by searching for all available articles on modifications of EVs (up to March 2021). Searches were made using keywords: "extracellular vesicles" (Medical Subject Headings (MeSH) OR "Click Chemistry" (MeSH) OR "Co-Incubation" (MeSH) OR "Chemical transfection" (MeSH) OR "Electroporation" (MeSH) OR "Sonication" (MeSH) OR "Extrusion" (MeSH) OR "Freeze-thaw" (MeSH)
OR "Genetic engineering" (MeSH) OR "Microfluidics" $(\mathrm{MeSH})$. Two investigators screened the titles, aims and abstracts of the published articles to determine eligible articles for the present study. The same investigators evaluated full-length articles, and inclusion and exclusion criteria were applied to each article. Moreover, the same investigators screened the references of the initial eligible articles to identify all eligible articles for inclusion in the final list.

\section{Inclusion and exclusion criteria}

Research papers screened during the literature search followed the following inclusion criteria for the present study: (1) Modification of EVs; (2) laboratory-based modification of EVs; (3) loading of drugs into the EVs, and (4) published an original article with all full-text literature and properly cited references. The following studies were excluded: (1) insufficient reported data with non-cited references; (2) published conference proceedings; (3) published review articles, letters, or text not in the English language; or (4) repetition of previously published articles.

\section{Data extraction}

The author's names, year of publication, country of origin, and types of methods used to modify the EVs were extracted. Outcomes were noted in the form of a bestsuited method for the modification of EVs that may have translational potential in clinical setup under GCP guidelines [27].

\section{Results}

A total of 1208 articles were screened; among them, 280 non-duplicate publications were identified. After the screening of titles and abstracts, 174 publications were excluded; then, another 70 published papers were excluded after the full-text screening of 106 published articles. The remaining 36 studies were included in this systematic review (Fig. 3). Network and density visualization of the studies included in this systematic review is demonstrated in Fig. 4.

\section{Study characteristics}

Study characteristics of the eligible studies showed that most authors performed EVs modification and functionalization using the freeze-thaw method and coincubation approach (Table 1). Seven studies used co-incubation to produce functional EVs that have a 


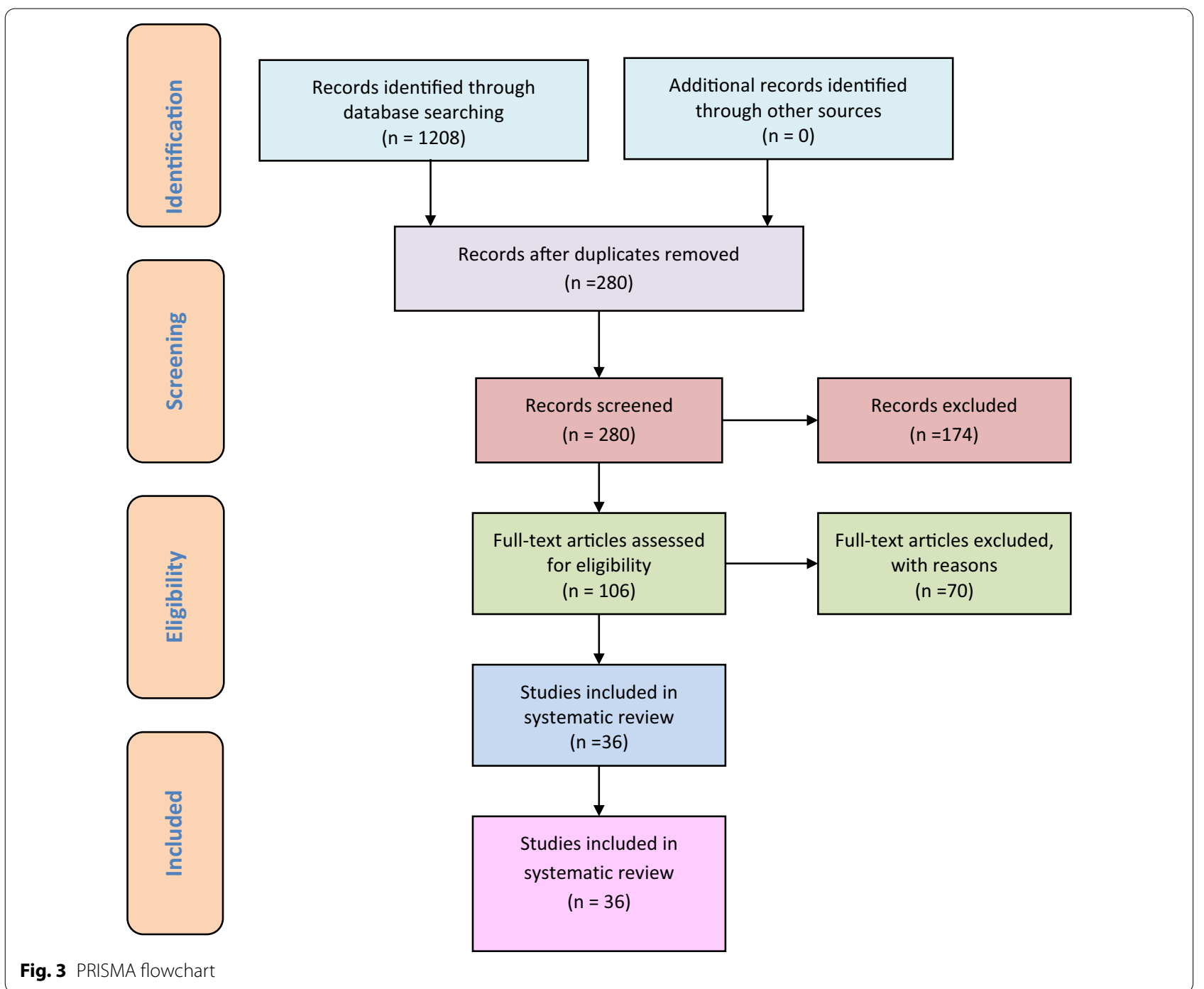

pioneering role in the treatment of various diseases, like cancer and other immunological complications. Moreover, eight eligible studies exploited the freezethaw approach for the surface modification of EVs. Click chemistry $(C C)$ [27-32], freeze-thawing, co-incubation [15, 33-38]. Two studies used chemical transfectionbased modification, which thus demonstrated the least preferred method for EVs modifications [39-44]. There were equal numbers of electroporation-assisted [41-44] and sonication approach-based [45-54] studies contributing four eligible studies each for EVs modification. Genetic engineering (GE) is gaining popularity as they are a widely used approach for EVs modification [55-59]. Moreover, microfluidics, a recently developed approach for EVs modification, showed the least number of studies (only two within the last 10 years) $[60,61]$.

\section{Systematic review}

Six studies exploited the CC approach for the modification of EVs [15, 31-35]. Two studies published in 2014 followed by one published in 2015 used a CC approach for the surface functionalization of EVs for targeted drug delivery. In one of the published studies, authors used copper-catalyzed azide-alkyne cyclo-addition of azide-fluor 545 with EVs to assess internalization [27]. The authors further noticed that a $50 \mathrm{kDa}$ exosomal protein efficiently binds 1.5 alkyne groups on its surface [27]. In a similar recently published study, the authors labeled the EVs surface with fluorescent probes using a $\mathrm{CC}$ approach to monitor the real-time tracking of EVs uptake within cells [28]. Similarly, CC has been exploited by authors for drug targeting, labeling of the EVs surface, 

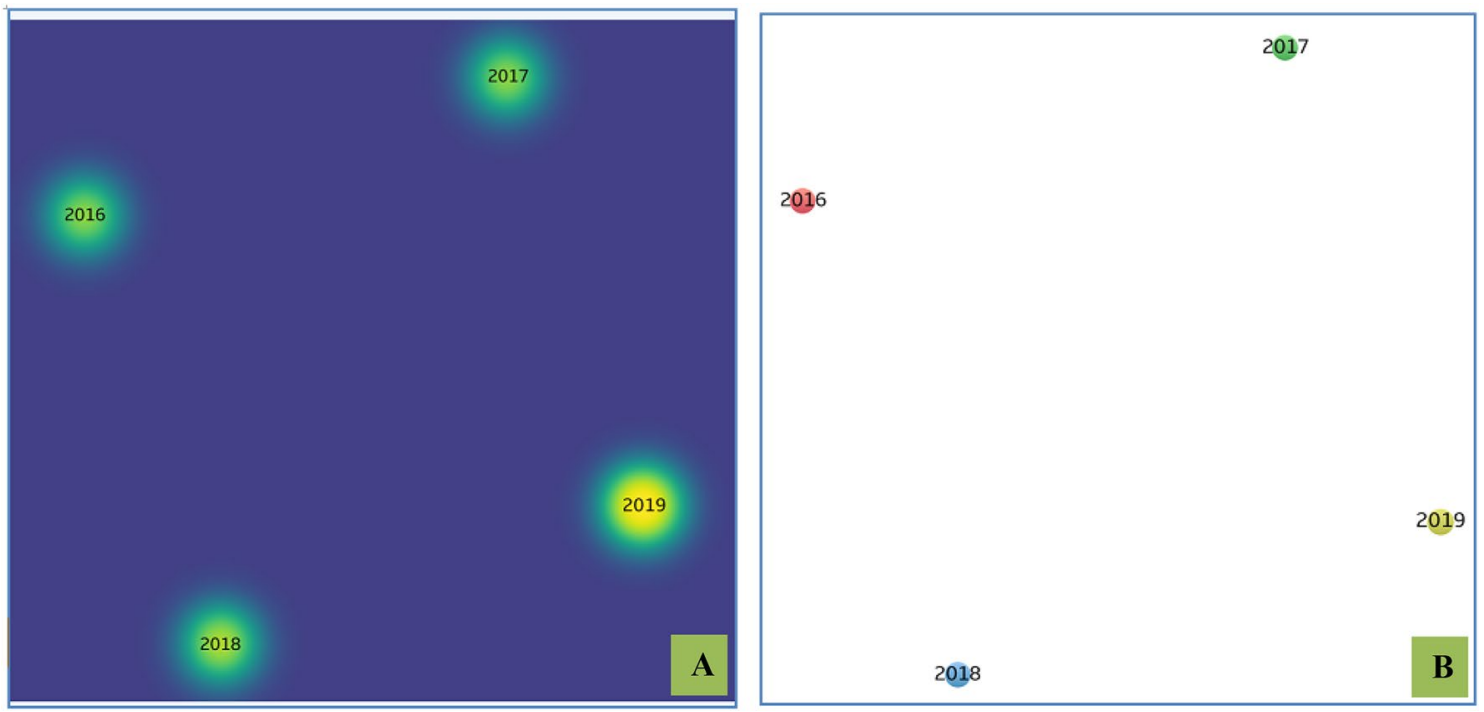

Fig. 4 A Network visualization of the studies distributed in the systematic review associated with the exosomal modifications. B Density visualization of the studies distributed in the systematic review

and attachment of probes for tracking [27-32]. The CC approach is quite popular and still is in use currently. CC is depicted in Fig. 5.

Click chemistry is associated with several advantages and disadvantages. The advantages being, it is cost-effective and can be initiated in water without the need for a deoxygenated environment. The absence of non-aromatic double bonds within bio-macromolecule restricts undesirable side chain reaction occurrence. This method is environmentally friendly. The main limitation associated with the click chemistry is the reducing agent that might reduce $\mathrm{Cu}+2$ to $\mathrm{Cu} 0$. This may be overcome by the incorporation of optimum concentration of reducing agent to catalyst ratio or using copper-stabilizing agents such as native cyclodextrins and tris- (hydroxyl propyltriazolylmethyl) amine (THPTA). Adverse impact on the human body is also among the main biological limitation of this approach. Excessive use of copper may lead to several associated side effects including neurological disorders. The main cause of toxicity associated with copper is the chemistry behind the reaction. Copper can readily accept and donate single electrons to change oxidation states thereby initiating in-vivo reduction of hydrogen peroxide to hydroxyl free radicals.

Co-incubation for exosomal modification is a popular method for dealing with nano-vesicles. In the present systematic review, seven studies used the co-incubation approach for the modification of EVs [15, 33-38]. In the co-incubation method, no external factor is applied to mediate the modification process. Figure 6 depicts the co-incubation method used for loading the target drug into EVs using a simple stirring process. In one study, the authors loaded sinoporphyrin sodium into EVs using the co-incubation approach, which was later used in therapeutic and imaging applications [34]. In another study on co-incubation, motile fluorescent sperm was noticed upon $48 \mathrm{~h}$ co-incubation with Vybrant dye-labeled EVs derived from endometrial cells [35]. In another study, EVs were loaded with curcumin using the co-incubation method for the treatment of brain inflammatory disease [15]. In another study, an engineering approach has been described in the modification of EVs [36]. Though proven to be useful for modification of EVs for their enhanced functionality with the desired cargo, this method is associated with some limitations as it affects the size of EVs, results in low yield, low entrapment and uncontrollable drug loading. It is a time-consuming approach due to passive diffusion. In this approach, a large amount of drug or cargo is needed to be delivered into the EVs. Hydrophilic cargo also faces problems in loading due to the outer lipid membrane of the EVs. However, it is a safe approach as it is non-toxic.

Chemical transfection or lipofectamine transfectionbased modification offers limited choices for using this safer approach. Only two studies claimed to exploit chemical transfection for exosomal modifications [39, 40]. In these two studies, authors used chemical transfection to deliver siRNA and the CRISPR/Cas9 system, respectively $[39,40]$. This approach is depicted in Fig. 7. Another advantage of using transfection agents like 


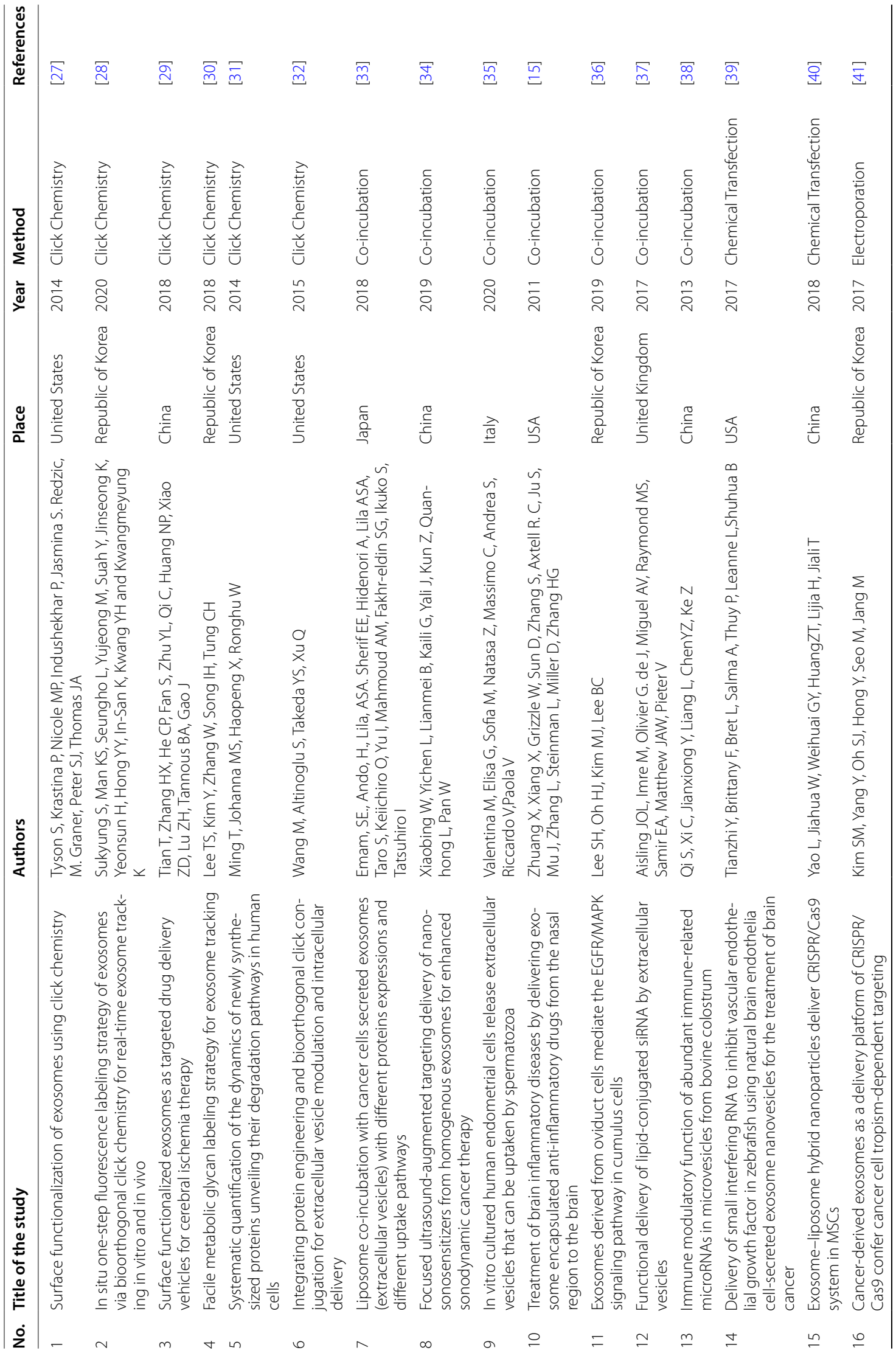




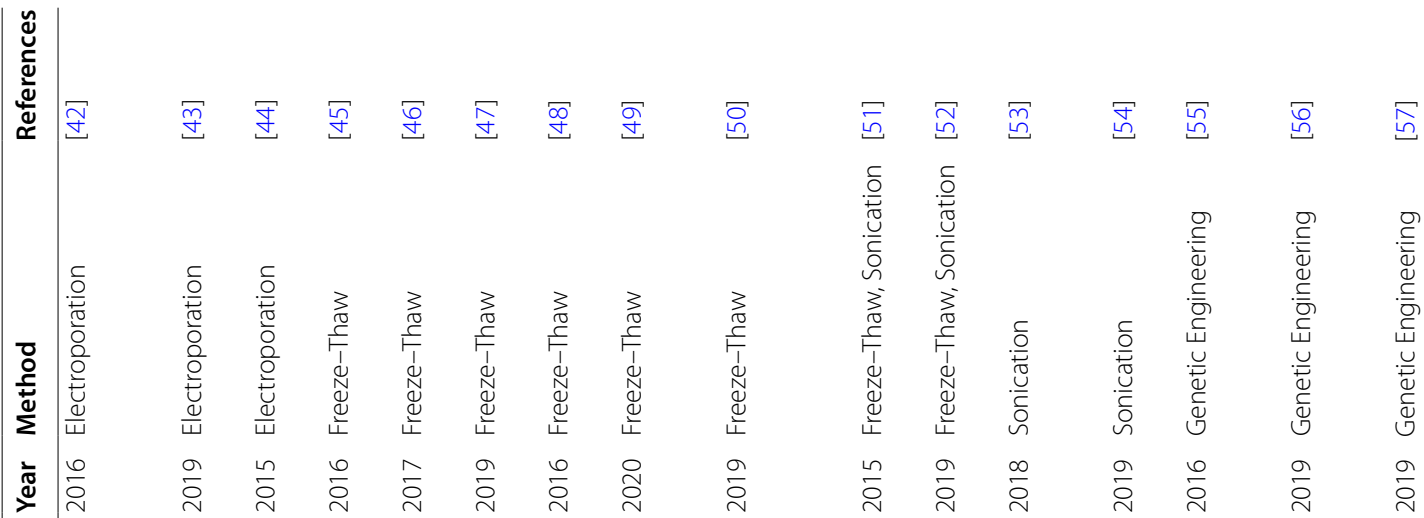

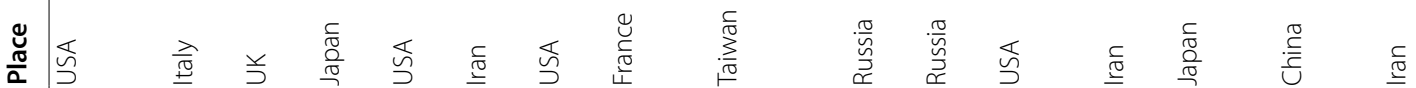

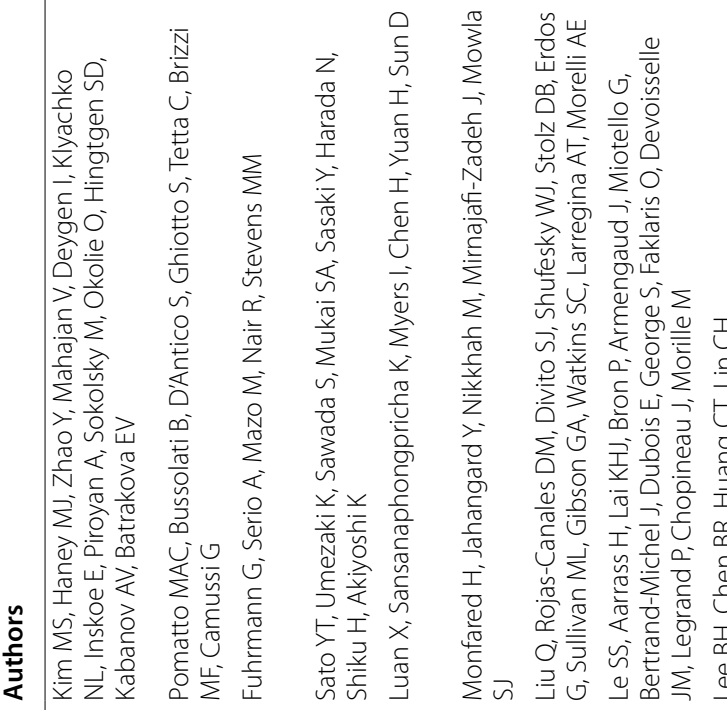

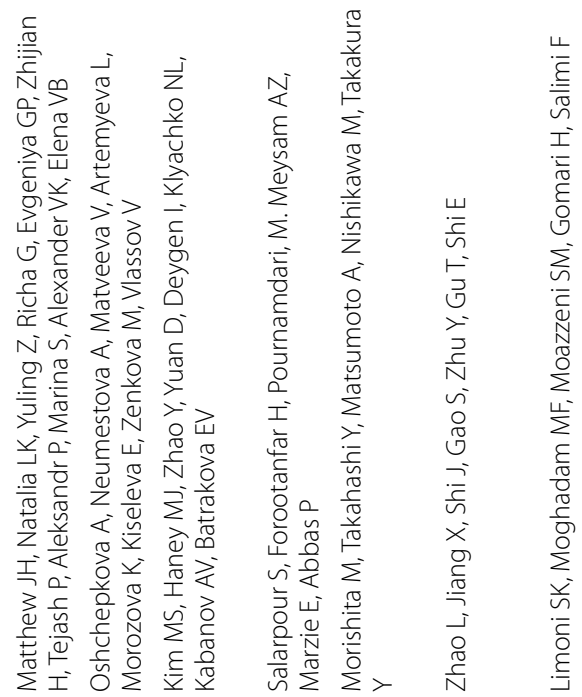




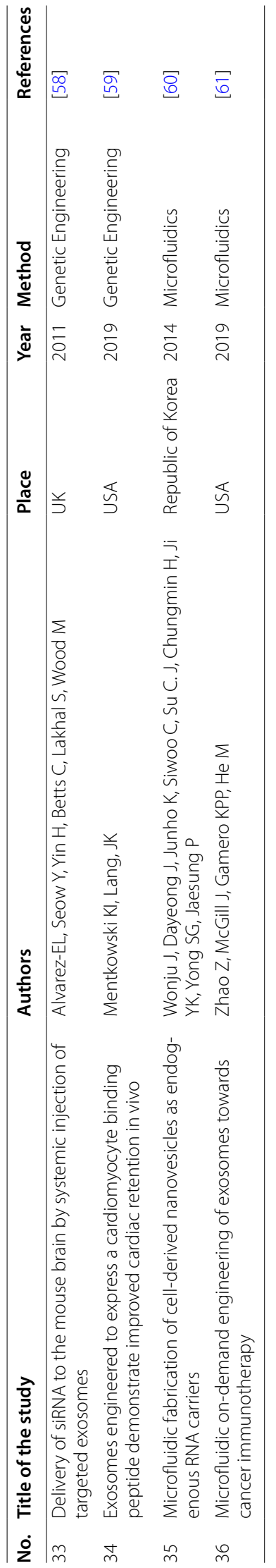




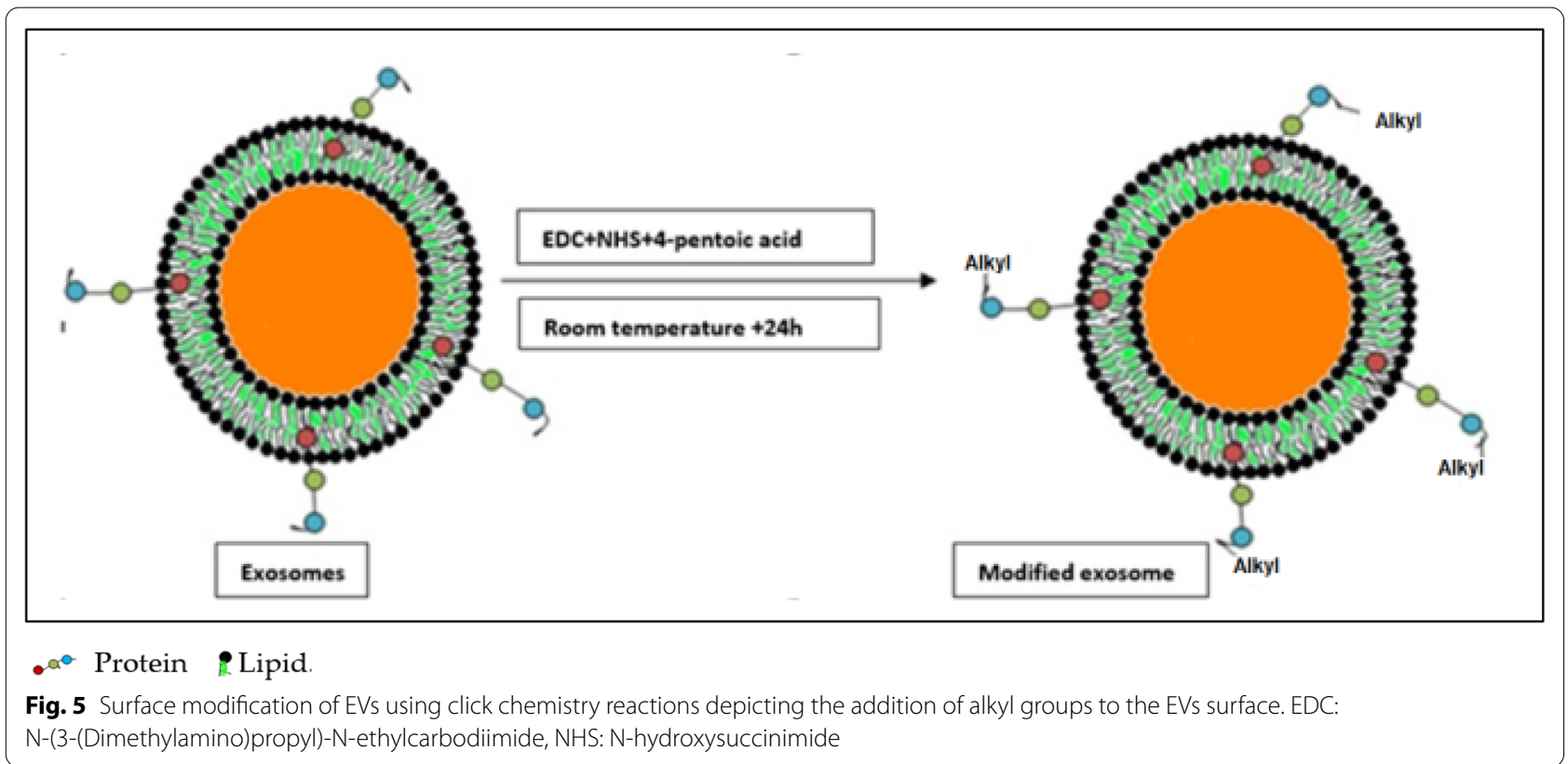

lipofectamine 2000 is that it can transfect a wide range of different cell types for a stable and longer duration. Moreover, the cons of this approach are cellular toxicity leading to high cell mortality along with immune rejections. Also, lipofectamine 2000 shows autofluorescence which might be interfering in fluorescence studies of delivering cargos. This approach is quite expensive and can't be recommended for scale-up implications.

Electroporation is another preferred method for the modification or loading of EVs for therapeutic and diagnostic purposes. In this method, an electrical field is applied to initiate the formation of pores in the lipid envelope of EVs in which the cargo of interest is placed; then, the membrane is resealed. Figure 8 shows a representation of the electroporation approach for loading of desired cargo. Four studies exploited the electroporation method [41-44]. In one of these studies, CRISPR/ Cas9 was loaded into EVs using electroporation [41], and another loaded the drug paclitaxel into EVs for cancer treatment [42]. Similarly, other studies mentioned in this systematic review used electroporation to modify EVs for the treatment of various cancers [43-45]. Electroporation is a convenient approach for large-sized molecules like siRNA that may not passively be loaded into the EVs using co-incubation of chemical transfection. Smaller sized cargo can be efficiently incorporated through this approach. However, some limitations are also associated with this approach such as aggregation of siRNA and EVs due to the application of electric current thereby reducing the loading efficiency of the system. Moreover, an electric current of higher intensity may cause nonreversible disturbance in the phospholipid bilayer thus disrupting the structural integrity of the EVs leading to instability of these vesicles. It is necessary to optimize the electric current application according to the size, nature and surface charge of the cargo that has to be delivered inside the EVs.

Eight studies used a freeze-thaw method for EVs modification [46-53]. Using freeze-thawing, Sato et al. fused EVs with liposomes to make engineered hybrid EVs [46]. Figure 9 depicts the fusion of liposomes and EVs through the freeze-thaw approach. Other studies also used this modification approach for a variety of applications, including cancer treatment, labeling, and loading of the desired cargo or drug into EVs [47-53]. This is the most widely used, preferred, and accepted method of EVs modification applied by researchers for drug targeting and therapeutics. The main advantage of this method is the maintenance of exosomal membrane integrity throughout the cargo loading process. Animal cells derived EVs shown stability at low temperatures and also the repeated freeze-thaw cycles cannot affect the physicochemical and structural properties. However, sometimes more cycles of repeated freeze-thaw may lead to aggregation of EVs thereby contributing to the broad size distribution of cargo. This approach has low efficiency of cargo loading compared to the sonication and extrusion approach. Repeated freeze-thaw cycles may also hamper 


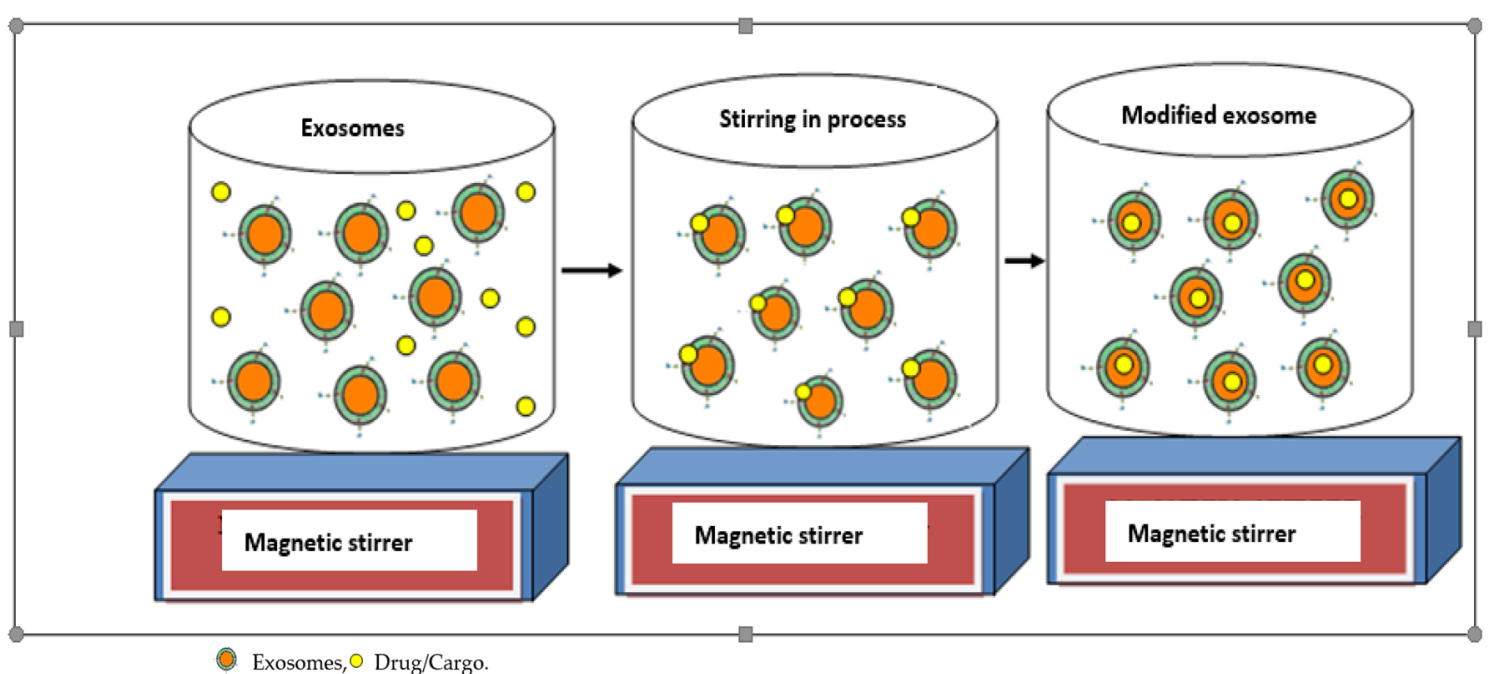

Fig. 6 Modification of EVs using co-incubation of EVs with the drug or cargo upon continuous stirring

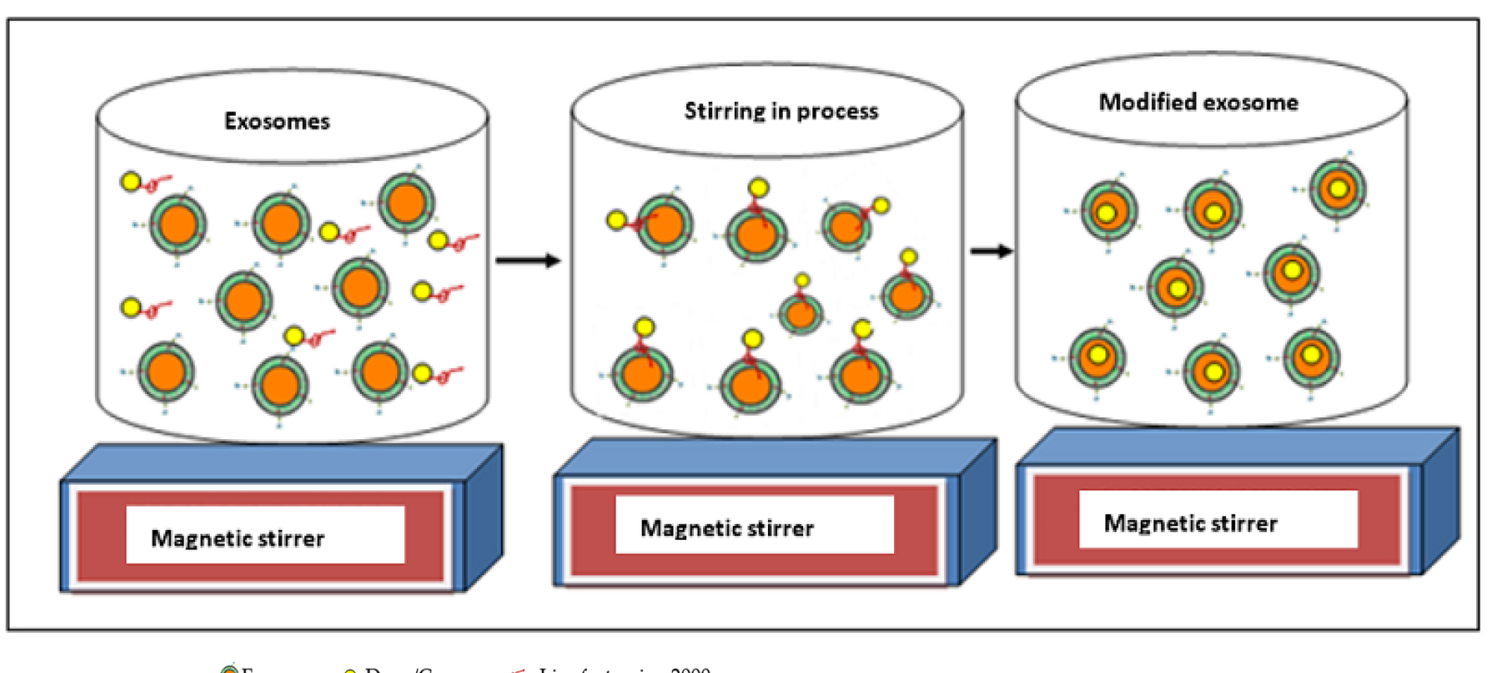

Exosomes, $\bigcirc$ Drug/Cargo, $\nleftarrow$ Lipofectamine 2000

Fig. 7 Modification of EVs using a chemical transfection agent, such as lipofectamine 2000

the fluorescence related study for the EVs due to the lipid dilution ratio.

Sonication is also among the preferable methods for loading drugs into EVs and surface modification. Four studies utilized sonication for the modification of EVs for various purposes [52-55]. The sonication method of loading cargo into EVs is suitable for biological molecules like small RNAs. This method has high loading efficiency too. Certain limitations like EVs membrane deformation, development of shearing forces, heat generation during the sonication cycle, loosing of EVs surface proteins and non-suitability for hydrophobic drug delivery are associated with this approach.

Genetic engineering of EVs is an easy and convenient approach for modification to deliver new characteristics. This approach was used in five studies [56-61]. AlvarezErviti and coworkers used genetic engineering to deliver siRNA into the mouse brain through systemic injection of targeted EVs [59]. Figure 10 shows the genetic engineering approach for the synthesis of engineered EVs. Using this approach parent's cells produce a homogenous population of EVs loaded with the fabricated or desired property. No cell toxicity was reported using this 


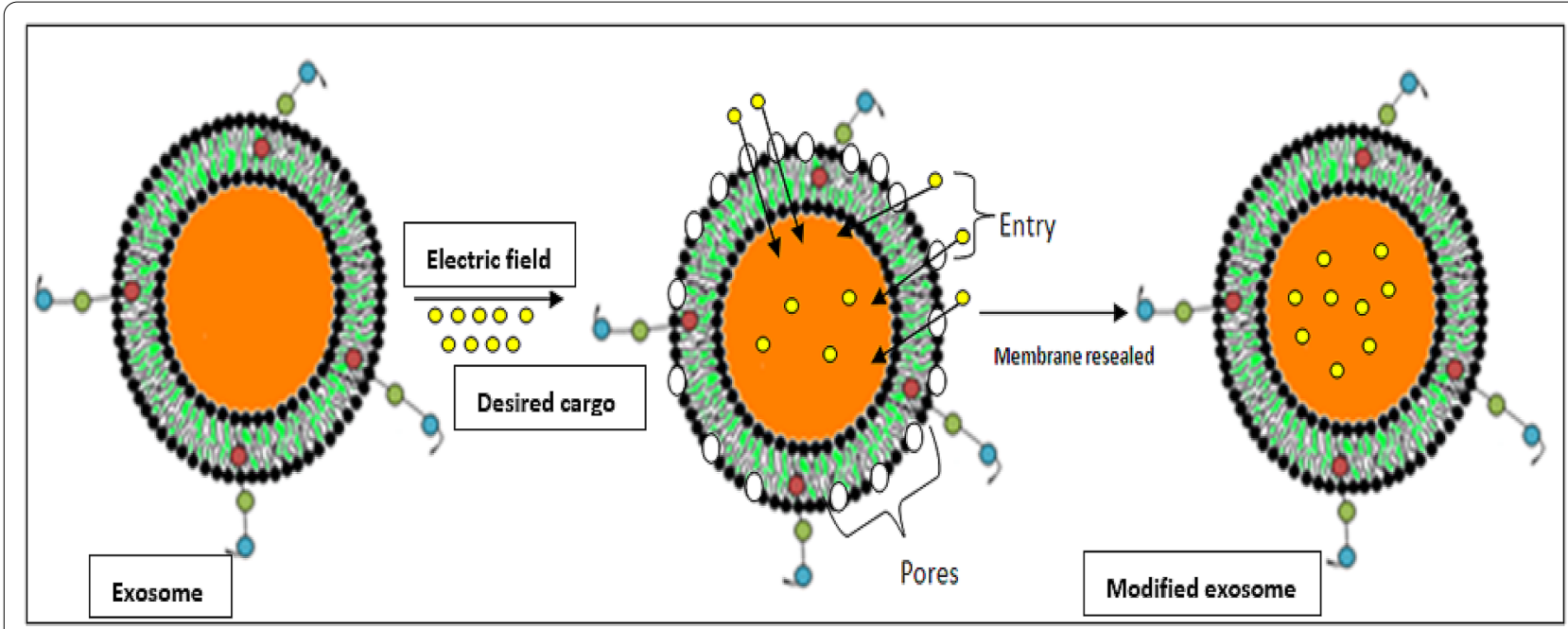

Protein Lipid O Pores

Fig. 8 Depiction of electroporation technique for delivering the desired cargo inside EVs through pores created under application of electric field

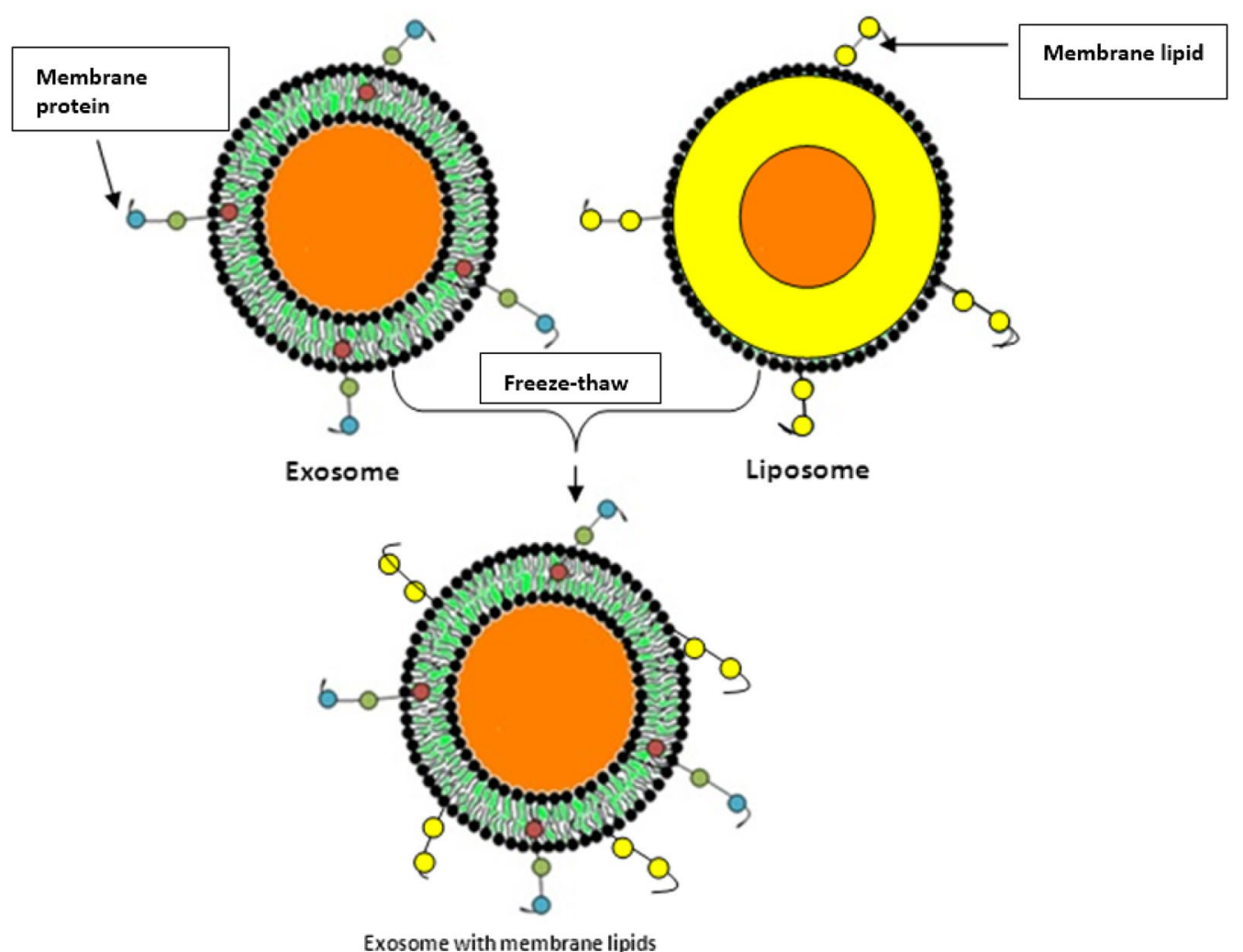

Fig. 9 Freeze-thaw approach of EVs surface modification 


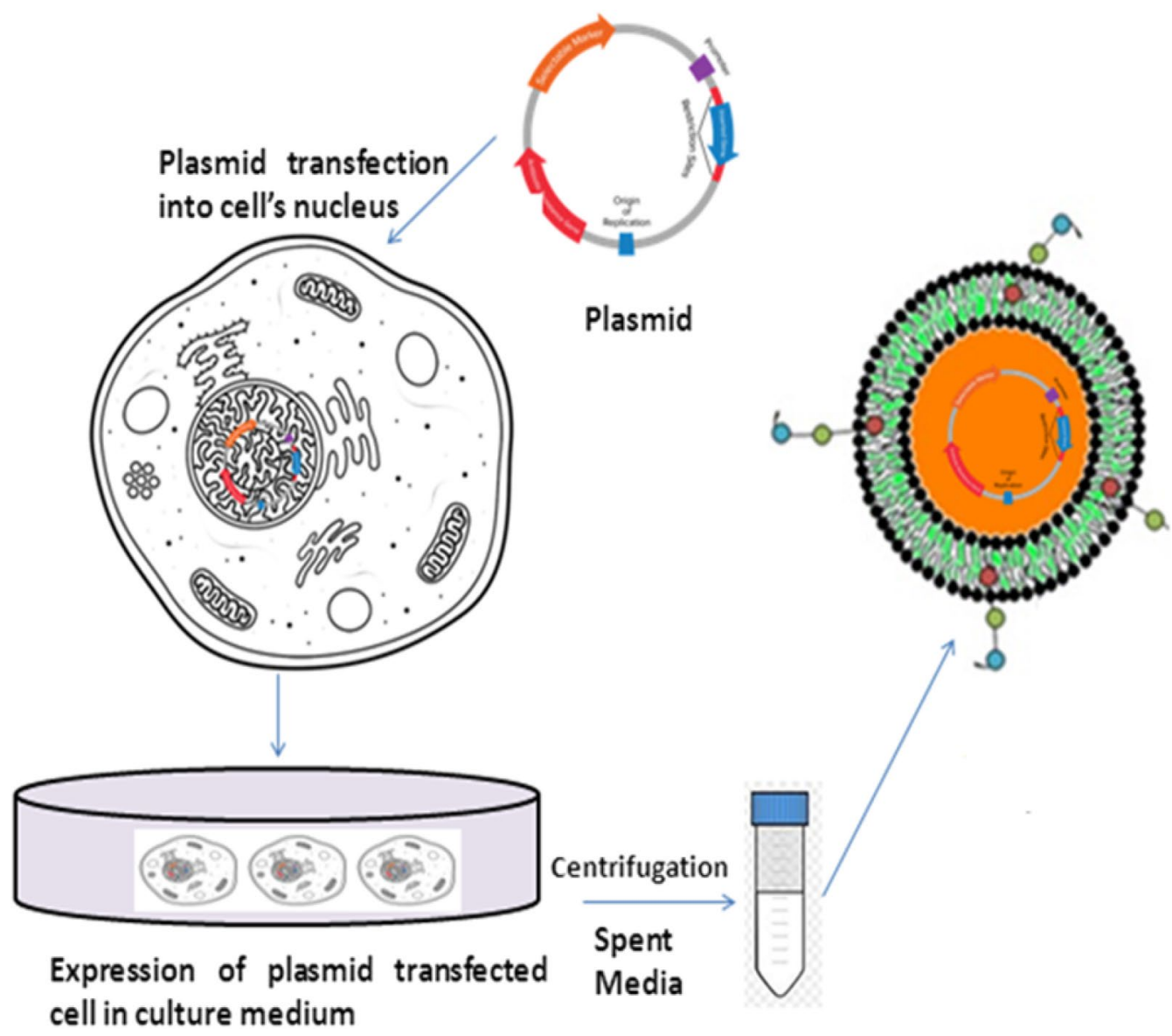

Fig. 10 Strategy for engineering EVs displaying targeting ligands. The figure is showing engineering approach for modification of EVs. The plasmid having desired gene of interest is inserted and transfected into the nucleus of the cells. Cell culturing of these transfected cells lead to secretion of EVs containing gene of interest

modification method. The versatility of this method is that it allows the loading of RNA, DNA, and peptides of choice into the EVs. Choice of specific EVs derived cells is an associated limitation of this method. Tumour derived EVs might interplay in the premetastatic niche and initiate negative effects. Although studies are not enough to decide the negative effects of these EVs derived from tumour cells. Another limitation is the use of the adenoviral gene; this is because in some cases humans have shown immune response.

Two authors have used a recently developed technique named microfluidics for EVs modification [60, 61]. The design of the microfluidics platform is shown in Fig. 11. In one study, microfluidics was utilized in the synthesis of synthetic EVs containing mRNAs, proteins with a shape similar to those used in drug delivery [60]. In another study, authors used a microfluidics approach by integrating cell harvesting, antigenic modifications, and photo-release of surface-engineered EVs on one polydimethylsiloxane (PDMS) platform [61]. Microfluidics technology is a recent approach for the modification of EVs with desired cargo. Due to its low cost, time saving, short processing time, preservation of EVs integrity, stability maintenance, high throughput precision, and low sample volume, this loading approach is gaining attention nowadays in EVs therapeutics. Another advantage of microfluidics is the opportunity to couple with automation that is helpful in mass-scale cargo loading for clinical settings. This technique offers a clear benefit over other cargo loading methods. The only disadvantage with this method is that sometimes polymeric material or non-EVs ingredient causes co-precipitation along with EVs.

\section{Discussion}

Through this detailed systematic analysis of the pioneer publications we gathered a global picture of the EVs modification approaches that can be exploited for efficient drug delivery. The significant increase in number of publications related to EVs modification; prove 


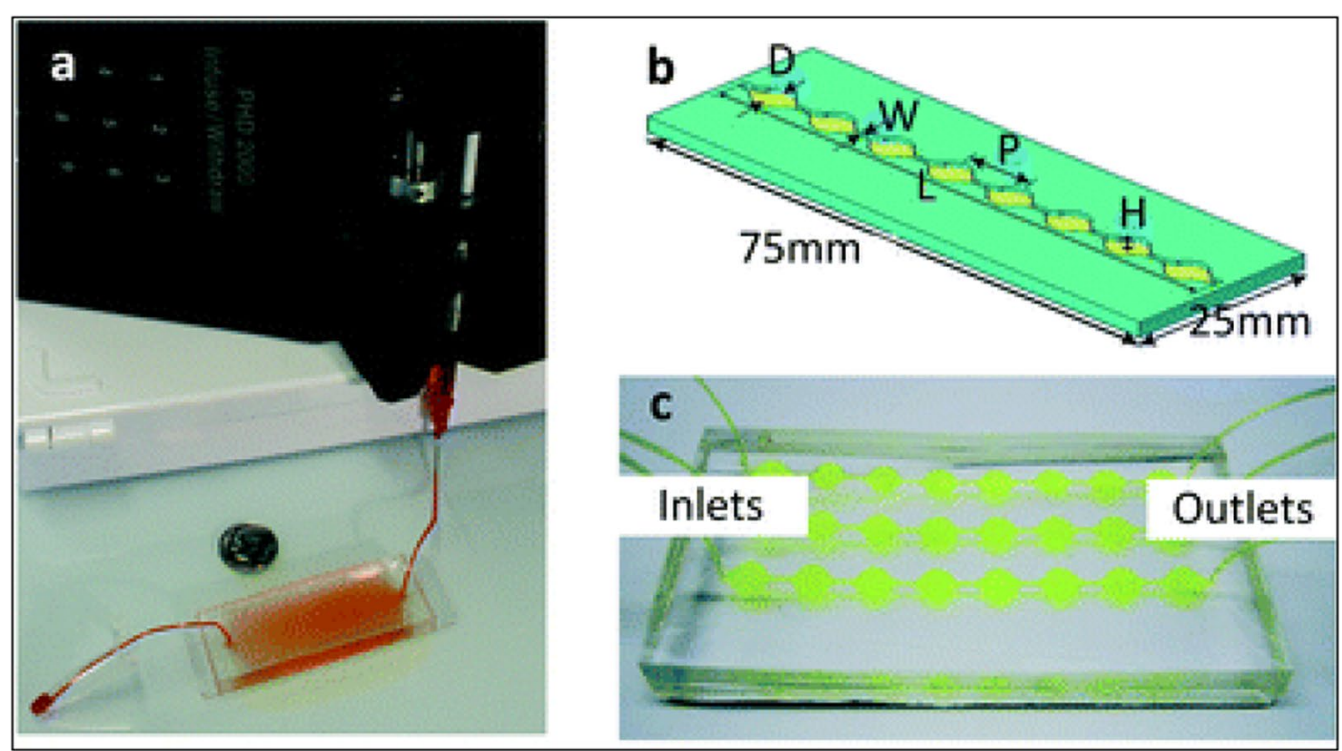

Fig. 11 a Microfluidics approach of microfluidic EVs isolation featured. The pump-assisted entry of EVs into micro channels of the device enable capturing of EVs that might be helpful in loading of the desired drug/cargo. b Single channel Exochip (c) Experimental setup using a 3 channels Exochip. (Adapted from Reference [64] under open access article distributed under the Creative Commons Attribution 3.0 Unported Licence)

their efficiency and capacity to carry out a vast array of therapeutic molecules in treatment of various diseases. These tailoring approaches further exploited the reprogramming of EVs, loading of desired targeted drugs, and tracking of EVs for diagnostics. Table 1 demonstrates the application of cargo-loaded EVs in the treatment of various human diseases. Considering the findings of the present study, the freeze-thaw method is the most recommended approach for the modification of EVs, followed by co-incubation.

The present systematic review analysis showed that freeze-thawing is a simple, easy, and time efficient physicochemical mechanism that can produce hybrid EVs due to membrane fusion. This process relies on the disruption of the lipid bilayer membrane due to the formation of temporary ice crystals [46]. In other words, this process could be described as the removal of water molecules present within hydrophilic moieties of the lipid bilayer membrane as the EVs freeze, thereby disrupting the structure of the EVs and initiating phase changes and reconstitution of the membrane. The authors of the cited studies successfully reprogrammed EVs by utilizing the freeze-thaw process [46-53].

This process involves several cycles of freezing (in liquid nitrogen, $-210{ }^{\circ} \mathrm{C}$ ) and thawing (at room temperature), which disturbs the EVs membrane integrity, thereby causing the cargo (liposomes, drugs, nano-particles, and peptides) to enter inside or fused with membrane as shown by recently published study (Fig. 9) [46]. In Table 2 various modification approaches were described that acted as a revolutionized tool in biotechnology. EVs were also been exploited as intervention therapy with the advancement in biotechnology, several clinical trials are various phases that decipher the potential of these EVs in treatment of several diseases as shown in Table 3.

The present study has some limitations that warrant consideration. Modifications of EVs through various other approaches have not been addressed in this systematic review. Additional clinical trials are needed to further validate the authenticity and global acceptability of specific modification approaches. However, the present study summarizes the most commonly used tailoring approaches for EVs modifications with future perspectives in therapeutics and diagnostics.

\section{Conclusion}

Extracellular vesicles exhibit promising therapeutic and diagnostic uses in biomaterials. These tailored nanovesicles can be loaded with desired biomolecules, such as proteins, lipids, nucleic acids, and drugs, using different modification approaches to obtain functionalized EVs. These functionalized EVs can be exploited in the treatment of various diseases, like cancer, inflammationassociated morbidities, and other cellular regeneration processes. Moreover, these loaded and functionalized EVs can also be investigated to elucidate the cellular uptake mechanism and for screening as a diagnostic tool. Several modification methods are available at present; however, the freeze-thaw and co-incubation 
Table 2 Modifications of extracellular vesicles and its role in nano-biotechnology

\begin{tabular}{|c|c|c|c|}
\hline EVs Type & Nanotechnological Modification & Application & Loading Method \\
\hline $\begin{array}{l}\text { Exosomes from mesenchymal stem } \\
\text { cells }\end{array}$ & $\begin{array}{l}\text { Glucose-coated gold nanoparticles } \\
\text { (NPs) }\end{array}$ & In vivo neuroimaging & Co-incubation \\
\hline Exosome from lung cancer or fibroblasts & Gold NPs and doxorubicin & Lung cancer treatment & Co-incubation \\
\hline EVs from breast adenocarcinoma & MOF NPs. NPs matrix contained gelonin & Inhibit adenocarcinoma growth & Sonication and extrusion \\
\hline Exosomes from Hela cells & MOF NPS & Hela cells & Co-incubation \\
\hline EVs from KB cells & ZnO NPs & Cytotoxic effect against KB cells & Co-incubation \\
\hline $\begin{array}{l}\text { EVs from endothelial, cancer and stem } \\
\text { cell lines }\end{array}$ & Porphyrins & To improve photodynamic therapy & $\begin{array}{l}\text { Electroporation, extru- } \\
\text { sion, saponin-assisted } \\
\text { and dialysis }\end{array}$ \\
\hline Exosomes from embryonic stem cells & Paclitaxel & Glioma therapy & Co-incubation \\
\hline Milk-derived exosomes & & To reduce paclitaxel's side effects & Co-incubation \\
\hline Exosomes from macrophages & & To overcome MDR in cancer cells & $\begin{array}{l}\text { Co-incubation, } \\
\text { electroporation and } \\
\text { sonication }\end{array}$ \\
\hline Exosomes from brain cell lines & & To treat brain tumor & Co-incubation \\
\hline EVs from prostatic cancer & & Cytotoxic effect against prostate cancer & Co-incubation \\
\hline $\begin{array}{l}\text { Exosomes from human colorectal } \\
\text { carcinoma }\end{array}$ & Doxorubicin & $\begin{array}{l}\text { Antiproliferative effect in colorectal } \\
\text { cancer }\end{array}$ & Dialysis \\
\hline Exosomes from breast cancer & & To treat breast and ovarian cancer & Electroporation \\
\hline Exosomes from breast cancer & & To reduce cardiotoxicity of doxorubicin & Electroporation \\
\hline $\begin{array}{l}\text { Exosomes from } 4 \mathrm{~T} 1, \mathrm{MCF}-7 \text {, and } \mathrm{PC} 3 \\
\text { cell line }\end{array}$ & & Breast cancer & Co-incubation \\
\hline $\begin{array}{l}\text { Exosomes from mouse immature } \\
\text { dendritic cells }\end{array}$ & & $\begin{array}{l}\text { For targeted delivery of chemothera- } \\
\text { peutic }\end{array}$ & Electroporation \\
\hline Milk-derived exosomes & Curcumin & Cervical cancer & Co-incubation \\
\hline Exosomes from lymphoma cells & & Activate myeloid cells in vivo & Co-incubation \\
\hline Plant exosomes & & Colon cancer & \\
\hline Milk-derived exosomes & $\begin{array}{l}\text { Paclitaxel, Docetaxel, Withaferin A and } \\
\text { curcumin }\end{array}$ & $\begin{array}{l}\text { Targeting and therapy of lung cancer } \\
\text { cells }\end{array}$ & Co-incubation \\
\hline Milk-derived exosomes & Celastrol & $\begin{array}{l}\text { Inhibition of } \mathrm{Hsp} 90 \text { and NF- } \mathrm{kB} \text { activa- } \\
\text { tion pathways in lung cancer }\end{array}$ & Co-incubation \\
\hline EVs from lung cancer & Oncolytic adenovirus and paclitaxel & $\begin{array}{l}\text { Enhance immunogenicity in lung } \\
\text { cancer }\end{array}$ & Co-incubation \\
\hline Exosomes from HEK 293 cells & SiRNA & Efficient delivery of siRNA in cancer cells & Electroporation \\
\hline Exosomes from HEK 293 cells & $\begin{array}{l}\text { Polo-like kinase } 1 \\
\text { (PLK-1) siRNA }\end{array}$ & $\begin{array}{l}\text { Silencing PLK-1 gene in bladder cancer } \\
\text { cells }\end{array}$ & Electroporation \\
\hline $\begin{array}{l}\text { Exosomes from HEK } 293 \text { and MCF-7 } \\
\text { cells }\end{array}$ & siRNA, miRNA and ssDNA ${ }^{b}$ & Oncogene knockdown & Sonication \\
\hline Plasma-derived EVs & miRNA cel-39 & $\begin{array}{l}\text { Promote apoptosis of hepatocellular } \\
\text { carcinoma }\end{array}$ & Electroporation \\
\hline
\end{tabular}

(Adapted from Ref No. [65]) under the Creative Commons Attribution License 
Table 3 EVs based intervention clinical trials (Source: clinicaltrials.gov)

\begin{tabular}{|c|c|c|c|c|c|c|}
\hline EVs Source & Condition & Drug & Administration Route & Dose Reported & Phase & Study Identifier \\
\hline MSCs & $\begin{array}{l}\text { Cerebrovascular disor- } \\
\text { ders/stroke }\end{array}$ & miR-124 & i.v & $200 \mu \mathrm{g}$ protein & $1 / 2$ & NCT03384433 \\
\hline MSCs & Alzheimer Disease & No & Nasal drip & $5 \mu \mathrm{g}-20 \mu \mathrm{g}$ & $1 / 2$ & NCT04388982 \\
\hline MSCs & Periodontitis & No & Local & Not reported & early 1 & NCT04270006 \\
\hline MSCs & Neuralgia & No & i.v. epineurally & $45 \mathrm{mg}, 15 \mathrm{mg}$ & $\mathrm{n} / \mathrm{a}$ & NCT04202783 \\
\hline MSCs & Depression & No & i.v & 21 million cells & $\mathrm{n} / \mathrm{a}$ & NCT04202770 \\
\hline MSCs & Diabetes Mellitus Type 1 & No & i.v & $\begin{array}{l}1.2 \times 1010-1.51 \times 1010 \\
\text { particles } / \mathrm{kg}\end{array}$ & $2 / 3$ & NCT02138331 \\
\hline MSCs & Chronic Ulcer & No & Topical & Not reported & 1 & NCT04134676 \\
\hline Plasma & Ulcer & No & Topical & Not reported & Early 1 & NCT02565264 \\
\hline MSC & $\begin{array}{l}\text { Dystrophic Epidermolysis } \\
\text { Bullosa }\end{array}$ & No & Topical & Not reported & $1 / 2$ & NCT04173650 \\
\hline MSCs & Multiple Organ Failure & No & i.v & $\begin{array}{l}150 \text { mg once a day for } 14 \\
\text { times }\end{array}$ & $\mathrm{n} / \mathrm{a}$ & NCT04356300 \\
\hline MSCs & Healthy & No & Inhalation & $\begin{array}{l}2 \times 108-20 \times 108 \text { parti- } \\
\text { cles } / 3 \mathrm{ml}\end{array}$ & 1 & NCT04313647 \\
\hline Plant & Colon Cancer & Curcumin & Oral & Not reported & 1 & NCT01294072 \\
\hline Plant & $\begin{array}{l}\text { Polycystic Ovary Syn- } \\
\text { drome }\end{array}$ & No & Oral & Not reported & $\mathrm{n} / \mathrm{a}$ & NCT03493984 \\
\hline Grape & $\begin{array}{l}\text { Head and Neck Cancer } \\
\text { Oral Mucositis }\end{array}$ & No & Oral & Not reported & 1 & NCT01668849 \\
\hline DCs & $\begin{array}{l}\text { Non Small Cell Lung } \\
\text { Cancer }\end{array}$ & $\begin{array}{l}\text { MHC class I- } \\
\text { class II- cancer } \\
\text { antigens }\end{array}$ & i.v & $\begin{array}{l}53-2422 \mu \mathrm{g} \text { protein/ } \\
\text { injection }\end{array}$ & 2 & NCT01159288 \\
\hline MSCs & $\begin{array}{l}\text { Pancreatic Adenocarci- } \\
\text { noma }\end{array}$ & KRAS G12D siRNA & i.v & $\begin{array}{l}\text { Days } 1,4 \text {, and } 10 \text { (dose } \\
\text { not reported) }\end{array}$ & 1 & NCT03608631 \\
\hline MSCs & SARS-CoV-2 pneumonia & No & Inhalation & $2 \times 108$ particles $/ 3 \mathrm{~mL}$ & 1 & NCT04276987 \\
\hline MSCs & SARS-CoV-2 pneumonia & No & Inhalation & $\begin{array}{l}0.5 \times 1010-2 \times 1010 \\
\text { particles } / 3 \mathrm{ml}\end{array}$ & $1 / 2$ & NCT04491240 \\
\hline Bone marrow & SARS-CoV-2 pneumonia & No & i.v & Not reported & 2 & NCT04493242 \\
\hline Human amniotic fluid & SARS-CoV-2 pneumonia & No & i.v & $\begin{array}{l}2 \times 1010-5 \times 1010 \\
\text { particles }\end{array}$ & $1 / 2$ & NCT04384445 \\
\hline MSCs & Dry Eye & No & Eye drop & $10 \mu \mathrm{g} / \mathrm{drop}$ & $1 / 2$ & NCT04213248 \\
\hline MSCs & Macular Holes & No & Drop & $50 \mu \mathrm{g}$ or $20 \mu \mathrm{g}$ & Early 1 & NCT03437759 \\
\hline
\end{tabular}

(Adapted from Ref No. [66]) under the Creative Commons Attribution License 4.0

approaches are preferred. Further clinical studies are needed to support specific modification approaches.

\section{Acknowledgements}

The authors would like to thank the Multidisciplinary Research Unit, Department of Health Research, Ministry of Health and Family Welfare, New Delhi for providing financial assistance in the form of salary to A.R.

\section{Authors' contributions}

AR: conceptualization, methodology, software, writing—original draft. G-B-J: visualization, investigation. writing - review \& editing. G-B-J: supervision, software, validation. All authors read and approved the final manuscript.

\section{Funding}

None.

\section{Data availability}

Not applicable.

\section{Declarations}

Ethics approval and consent to participants Not applicable.

\section{Consent for publication}

All authors have given consent for publication.

\section{Competing interests}

The authors declare that they have no competing interests.

\section{Author details}

${ }^{1}$ Multidisciplinary Research Unit, Department of Health Research, MoHFW, GSVM Medical College, Kanpur, India 208002. ${ }^{2}$ Department of Anatomy and Cell Biology, College of Medicine, Gachon University, 155 Getbeol-roYeonsu-gu, Incheon 21999, Korea.

Received: 2 October 2021 Accepted: 20 December 2021

Published online: 30 December 2021 


\section{References}

1. Xu R, Rai A, Chen M, Suwakulsiri W, Greening DW, Simpson RJ. Extracellular vesicles in cancer-implications for future improvements in cancer care. Nat Rev ClinOncol. 2018;10:617-38.

2. Raghav A, Khan ZA, Upadhayay VK, Tripathi P, Gautam KA, Mishra BK, Ahmad J, Jeong G. Mesenchymal stem cell-derived exosomes exhibit promising potential for treating SARS-CoV-2-infected patients. Cells. 2021;10:587.

3. Raghav A, Tripathi P, Mishra BK, Jeong GB, Banday S, Gautam KA Mateen QN, Singh P, Singh M, Singla A, Ahmad J. Mesenchymal stromal cell-derived tailored exosomes treat bacteria-associated diabetes foot ulcers: a customized approach from bench to bed. Front Microbiol. 2021;12:712588.

4. Raposo G, Stoorvogel W. Extracellular vesicles: exosomes, microvesicles and friends. J Cell Biol. 2013;200:373-83.

5. Lewis JM, Vyas AD, Qiu Y, Messer KS, White R, Heller MJ. Integrated analysis of exosomal protein biomarkers on alternating current electrokinetic chips enables rapid detection of pancreatic cancer in patient blood. ACS Nano. 2018;12(4):3311-20.

6. Cavallaro S, Horak J, Hååg P, Gupta D, Stiller C, Sahu SS, Görgens A, Gatty HK, Viktorsson K, El Andaloussi S, Lewensohn R, Karlström AE, Linnros J, Dev A. Label-free surface protein profiling of extracellular vesicles by an electrokinetic sensor. ACS Sens. 2019;4(5):1399-408.

7. Yan Z, Dutta S, Liu Z, Yu X, Mesgarzadeh N, Ji F, Bitan G, Xie YH. A labelfree platform for identification of exosomes from different sources. aCS Sens. 2019;2:488-97.

8. He S, Liu G, Zhu X. Human breast milk-derived exosomes may help maintain intestinal epithelial barrier integrity. Pediatr Res. 2021;90:366-72.

9. Sun Y, Huo C, Qiao Z, Shang Z, Uzzaman A, Liu S, Jiang X, Fan LY, Ji L, Guan X, Cao CX, Xiao H. Comparative proteomic analysis of exosomes and microvesicles in human saliva for lung cancer. J Proteome Res. 2018;17:1101-7.

10. Patel GK, Khan MA, Zubair H, Srivastava SK, Khushman M, Singh S, Singh AP. Comparative analysis of exosome isolation methods using culture supernatant for optimum yield, purity and downstream applications. Sci Rep. 2019;9(1):5335.

11. Lötvall J, Hill AF, Hochberg F, Buzás El, Di Vizio D, Gardiner C, Gho YS, Kurochkin IV, Mathivanan S, Quesenberry P, Sahoo S, Tahara H, Wauben MH, Witwer KW, Théry C. Minimal experimental requirements for definition of extracellular vesicles and their functions: a position statement from the International Society for Extracellular Vesicles. J Extracell Vesicles. 2014;1:26913

12. Bertrand N, Leroux JC. The journey of a drug-carrier in the body: an anatomo-physiological perspective. J Controlled Release. 2012;161:152-63.

13. Lai $C P$, Breakefield $X O$. Role of exosomes/microvesicles in the nervous system and use in emerging therapies. Front Physiol. 2012;3:228.

14. El Andaloussi S, Lakhal S, Mager I, Wood MJ. Exosomes for targeted siRNA delivery across biological barriers. Adv Drug Deliv Rev. 2013;65:391-7.

15. Zhuang X, Xiang X, Grizzle W, Sun D, Zhang S, Axtell RC, Ju S, Mu J, Zhang L, Steinman L, Miller D, Zhang HG. Treatment of brain inflammatory diseases by delivering exosome encapsulated anti-inflammatory drugs from the nasal region to the brain. Mol Ther. 2011;19:1769-79.

16. Lee Y, El Andaloussi S, Wood MJ. Exosomes and microvesicles: extracellular vesicles for genetic information transfer and gene therapy. Hum Mol Genet. 2012;21:R125-34.

17. Iraci N, Leonardi T, Gessle F, Vega B, Pluchino S. Focus on extracellular vesicles: physiological role and signaling properties of extracellular membrane vesicles. Int J Mol Sci. 2016;17:171.

18. Bakht M, Winter C, Simons M. Inhibition of myelin membrane sheath formation by oligodendrocyte-derived exosome-like vesicles. J Biol Chem. 2011:286:787-96.

19. Pusic KM, Pusic AD, Kraig RP. Environmental enrichment stimulates immune cell secretion of exosomes that promote CNS myelination and may regulate inflammation. Cell Mol Neurobiol. 2016;36:313-25.

20. Sahoo S, Klychko E, Thorne T, Misener S, Schultz KM, Millay M, Ito A, Liu T, Kamide C, Agrawal H, Perlman H, Qin G, Kishore R, Losordo DW. Exosomes from human CD34(+) stem cells mediate their proangiogenic paracrine activity. Circ Res. 2011;109:724-8.
21. Lai RC, Arslan F, Lee MM, Sze NS, Choo A, Chen TS, Salto-Tellez M, Timmers L, Lee CN, El Oakley RM, Pasterkamp G, de Kleijn DP, Lim SK. Exosome secreted by MSC reduces myocardial ischemia/reperfusion injury. Stem Cell Res. 2010;4:214-22.

22. Zhang M, Zang X, Wang M, Li Z, Qiao M, Hu H, Chen D. Exosome-based nanocarriers as bio-inspired and versatile vehicles for drug delivery: recent advances and challenges. J Mater Chem B. 2019;7:2421.

23. Zhang Y, Liu Y, Liu H, Tang WH. Exosomes: biogenesis, biologic function and clinical potential. Cell Biosci. 2019;9(19):1-18.

24. Zhang G, Yang P. A novel cell-cell communication mechanism in the nervous system: exosomes. J Neurosci Res. 2018;96:45-52.

25. Maroto R, Zhao Y, Jamaluddin M, Popov VL, Wang H, Kalubowilage M, Zhang Y, Luisi J, Sun H, Culbertson CT, Bossmann SH, Motamedi M, Brasier AR. Effects of storage temperature on airway exosome integrity for diagnostic and functional analyses. J Extracell Vesicles. 2017;6:1359478.

26. Melissa L, Rethlefsen S, Kirtley S, Waffenschmidt A, Patricia A, David M, Page MJ, Koffel JB, PRISMA-S Group. PRISMA-S: an extension to the PRISMA Statement for Reporting Literature Searches in Systematic Reviews. Syst Rev. 2021;10:39.

27. Tyson S, Krastina P, Payton NM, Persaud I, Jasmina S, Michael RW, Graner PS, Thomas JA. Surface functionalization of exosomes using click chemistry. Bioconjugate Chem. 2014;25:1777-84.

28. Song S, Shim M, Lim S, Moon Y, Yang S, Kim J, Hong Y, Kim Y, Hwang S, Kim K. In situ one-step fluorescence labeling strategy of exosomes via bioorthogonal click chemistry for real-time exosome tracking in vitro and in vivo. Bioconjugate Chem. 2020;13:1562-74.

29. Tian T, Zhang HX, He CP, Fan S, Zhu YL, Qi C, Huang NP, Xiao ZD, Lu $\mathrm{ZH}$, Tannous BA, Gao J. Surface functionalized exosomes as targeted drug delivery vehicles for cerebral ischemia therapy. Biomaterials. 2018;150:137-49

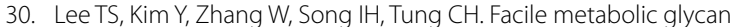
labeling strategy for exosome tracking. Biochim Biophys Acta Gen Subj. 2018;1862:1091-100

31. Ming T, Smeekens JM, Xiao H, Wu R. Systematic quantification of the dynamics of newly synthesized proteins unveiling their degradation pathways in human cells. Chem Sci. 2020;11:3557-68.

32. Wang M, Altinoglu S, Takeda YS, Xu Q. Integrating protein engineering and bioorthogonal click conjugation for extracellular vesicle modulation and intracellular delivery. PLOS ONE. 2015;10:e0141860.

33. Emam SE, Ando H, Lila ASA, Shimizu T, Okuhira K, Yu I, Mahmoud A, Mahdy FS, Ghazy IS, Tatsuhiro I. Liposome co-incubation with cancer cells secreted exosomes (extracellular vesicles) with different proteins expressions and different uptake pathways. Sci Rep. 2018;8:14493.

34. Liu Y, Bai L, Guo K, Jia Y, Zhang K, Liu Q, Wang P, Wang X. Focused ultrasound-augmented targeting delivery of nano-sonosensitizers from homogenous exosomes for enhanced sonodynamic cancer therapy. Theranostics. 2019;9:5261-81.

35. Murdica V, Giacomini E, Makieva S, Zarovni N, Candiani M, Salonia A, Vago $R$, Viganò $P$. In vitro cultured human endometrial cells release extracellular vesicles that can be uptaken by spermatozoa. Sci Rep. 2020;10:8856.

36. Fu S, Yi W, Xia X, Zheng JC. Exosome engineering: Current progress in cargo loading and targeted delivery. Nano Impact. 2020;20:100261.

37. O'Loughlin AJ, Mäger I, de Jong OG, Varela MA, Schiffelers RM, El Andaloussi S, Wood MJA, Vader P. Functional delivery of lipid-conjugated siRNA by extracellular vesicles. MolTher. 2017:25:1580-7.

38. Sun Q, Chen X, Yu J, Zen K, Zhang CY, Li L. Immune modulatory function of abundant immune-related microRNAs in microvesicles from bovine colostrums. Protein Cell. 2013:4:197-210.

39. Yang T, Fogarty B, LaForge B, Aziz S, Pham T, Lai L, Bai S. Delivery of small interfering RNA to inhibit vascular endothelial growth factor in Zebrafish using natural brain endothelia cell-secreted exosome nanovesicles for the treatment of brain cancer. AAPS J. 2017:19:475-86.

40. Lin Y, Wu J, Gu W, Huang Y, Tong Z, Huang L, Tan J. Exosome-liposome hybrid nanoparticles deliver CRISPR/Cas9 sys-tem in MSCs. Adv Sci. 2018;5:1700611.

41. Kim SM, Yang Y, Oh SJ, Hong Y, Seo M, Jang M. Cancer-derived exosomes as a delivery platform of CRISPR/Cas9 confer cancer cell tropism-dependent targeting. J Control Release. 2017;266:8-16. 
42. Kim MS, Haney MJ, Zhao Y, Mahajan V, Deygen I, Klyachko NL, Inskoe E, Piroyan A, Sokolsky M, Okolie O, Hingtgen SD, Kabanov AV, Batrakova EV. Development of exosome-encapsulated paclitaxel to overcome MDR in cancer cells. Nano Med. 2017;12:655-64.

43. Pomatto MAC, Bussolati B, D'Antico S, Ghiotto S, Tetta C, Brizzi MF, Camussi G. Improved loading of plasma-derived extracellular vesicles to encapsulate antitumor miRNAs. Mol Ther Methods ClinDev. 2019;13:133-44

44. Fuhrmann G, Serio A, Mazo M, Nair R, Stevens MM. Active loading into extra-cellular vesicles significantly improves the cellular uptake and photodynamic effect of porphyrins. J Control Release. 2015;205:35-44

45. Sato YT, Umezaki K, Sawada S, Mukai SA, Sasaki Y, Harada N, Shiku H, Akiyoshi K. Engineering hybrid exosomes by membrane fusion with liposomes. Sci Rep. 2016;6:21933.

46. Luan X, Sansanaphongpricha K, Myers I, Chen H, Yuan H, Sun D. Engineering exosomes as refined biological nano-platforms for drug delivery. Acta Pharmacol Sin. 2017;38:754-63.

47. Monfared $\mathrm{H}$, Jahangard $\mathrm{Y}$, Nikkhah M, Mirnajafi-Zadeh J, Mowla SJ. Potential therapeutic effects of exosomes packed with a miR-21-sponge construct in a rat model of glioblastoma. Front Oncol. 2019;9:782.

48. Liu Q, Rojas-Canales DM, Divito SJ, Shufesky WJ, Stolz DB, Erdos G, Sullivan ML, Gibson GA, Watkins SC, Larregina AT, Morelli AE. Donor dendritic cellderived exosomes promote allograft-targeting immune response. J Clin Invest. 2016;126:2805-20.

49. Le Saux S, Aarrass H, Lai-Kee-Him J, Bron P, Armengaud J, Miotello G, Bertrand-Michel J, Dubois E, George S, Faklaris O, Devoisselle JM, Legrand P, Chopineau J, Morille M. Post-production modifications of murine mesenchymal stem cell (mMSC) derived extracellular vesicles(EVs) and impact on their cellular interaction. Biomaterials. 2020;231:119675.

50. Lee B, Chen B, Huang C, Lin C. The immune activity of PT-peptide derived from anti-lipopolysaccharide factor of the swimming crab Portunustrituber-culatus is enhanced when encapsulated in milk-derived extracellular vesicles. Mar Drugs. 2019;17:248.

51. Haney MJ, Klyachko NL, Zhao Y, Gupta R, Plotnikova EG, He Z, Patel T, Piroyan A, Sokolsky M, Kabanov AV, Batrakova EV. Exosomes as drug delivery vehicles for parkinson's disease therapy. J Control Release. 2015;207:18-30.

52. Oshchepkova A, Neumestova A, Matveeva V, Artemyeva L, Morozova K, Kiseleva E, Zenkova M, Vlassov V. Cytochalasin-B-inducible nanovesicle mimics of natural extracellular vesicles that are capable of nucleic acid transfer. Micromachines. 2019;10:750.

53. Kim MS, Haney MJ, Zhao Y, Yuan D, Deygen I, Klyachko NL, Kabanov AV, Batrakova EV. Engineering macrophage-derived exosomes for targeted paclitaxel delivery to pulmonary metastases: in vitro and in vivo evaluations. Nanomedicine. 2018;14:195-204.

54. Salarpour S, Forootanfar H, Pournamdari M, Meysam A, Marzie E, Abbas P. Paclitaxel incorporated exosomes derived from glioblastoma cells: comparative study of two loading techniques. DARU J Pharm Sci. 2019;27:533-9.

55. Morishita M, Takahashi Y, Matsumoto A, Nishikawa M, Takakura Y. Exosome-based tumor antigens-adjuvant co-delivery utilizing genetically engineered tumor cell-derived exosomes with immunostimulatory CpG DNA. Biomaterials. 2016;111:55-65.

56. Zhao L, Jiang X, Shi J, Gao S, Zhu Y, Gu T, Shi E. Exosomes derived from bone marrow mesenchymal stem cells overexpressing microRNA-25 protect spinal cords against transient ischemia. J Thorac Cardiovasc Surg. 2019;157:508-17.

57. Limoni SK, Moghadam MF, Moazzeni SM, Gomari H, Salimi F. Engineered exosomes for targeted transfer of siRNA to HER2 positive breast cancer cells. Appl Biochem Biotechnol. 2019;187:352-64.

58. Alvarez-Erviti L, Seow Y, Yin H, Betts C, Lakhal S, Wood M. Delivery of siRNA to the mouse brain by systemic injection of targeted exosomes. Nat Biotechnol. 2011;29:341-5.

59. Mentkowski Kl, Lang JK. Exosomes engineered to express a cardiomyocyte binding peptide demonstrate improved cardiac retention in vivo. Sci Rep. 2019;9:10041.

60. Jo W, Jeong D, Kim J, Cho S, Jang S, Han C, Kang J, Gho YS, Park J. Microfluidic fabrication of cell-derived nanovesicles as endogenous RNA carriers. Lab Chip. 2014;14:1261-9.

61. Zhao Z, McGill J, Gamero KPP, He M. Microfluidic on-demand engineering of exosomes towards cancer immunotherapy. Lab Chip. 2019;19:1877-86.
62. Yi YW, Lee JH, Kim SY, Pack CG, Ha DH, Park SR, Youn J, Cho BS. Advances in analysis of biodistribution of exosomes by molecular imaging. Int J Mol Sci. 2020;21:665.

63. Ale Ebrahim S, Ashtari A, Zamani Pedram M, Ale Ebrahim N, SanatiNezhad A. Publication trends in exosomes nanoparticles for cancer detection. Int J Nanomedicine. 2020;15:4453-70.

64. Liga A, Vliegenthart ADB, Oosthuyzen W, Dear JW, Kersaudy-Kerhoas M. Exosome isolation: a microfluidic road-map. Lab Chip. 2015;15:2388.

65. Susa F, Limongi T, Dumontel B, Vighetto V, Cauda V. Engineered extracellular vesicles as a reliable tool in cancer. Nanomed Cancers (Basel). 2019;11:1979.

66. Klyachko NL, Arzt CJ, Li SM, Gololobova OA, Batrakova EV. Extracellular vesicle-based therapeutics: preclinical and clinical investigations. Pharmaceutics. 2020;12:1171.

67. Bazzan E, Tinè M, Casara A, Biondini D, Semenzato U, Cocconcelli E, Balestro E, Damin M, Radu CM, Turato G, Baraldo S, Simioni P, Spagnolo P, Saetta M, Cosio MG. Critical review of the evolution of extracellular vesicles' knowledge: from 1946 to Toda. Int J Mol Sci. 2021;22:6417.

\section{Publisher's Note}

Springer Nature remains neutral with regard to jurisdictional claims in published maps and institutional affiliations.
Ready to submit your research? Choose BMC and benefit from:

- fast, convenient online submission

- thorough peer review by experienced researchers in your field

- rapid publication on acceptance

- support for research data, including large and complex data types

- gold Open Access which fosters wider collaboration and increased citations

- maximum visibility for your research: over $100 \mathrm{M}$ website views per year

At BMC, research is always in progress.

Learn more biomedcentral.com/submissions 